\title{
USULAN PERBAIKAN PENEMPATAN PRODUK PADA GUDANG PRODUK JADI DENGAN MENGGUNAKAN METODE DEDICATED STORAGE
}

\author{
YEVITA NURSYANTI \\ Manajemen Logistik Industri Elektronika, Politeknik APP \\ Jalan Timbul No. 34, RT 6/RW 5, Ciganjur, Jagakarsa, \\ Kota Jakarta Selatan, DKI Jakarta 12630 \\ Email: yevita.nursyanti@gmail.com
}

\begin{abstract}
Salah satu ciri tata letak yang baik yaitu memiliki efisiensi dalam pengambilan maupun penerimaan barang di dalam gudang. Penelitian ini melakukan perhitungan dan menganalisis usulan tata letak gudang produk jadi dengan menggunakan metode dedicated storage. Data yang digunaka adalah data produksi, data penjualan, dan data penyimpanan. Metode yang digunakan adalah dedicated storage. Adapun tujuan dari metode ini adalah untuk memberikan usulan perbaikan tata letak gudang produk jadi yang lebih fleksibel terhadap pemindahan produk jadi di gudang, mendapatkan rancangan tata letak gudang produk jadi yang efektif, meminimalkan biaya simpan pada gudang dengan menghemat pemindahan dan pengaturan barang dalam gudang produk jadi. Adapun hasil dari perhitungan tersebut didapatkan layout usulan dengan jarak tempuh sebesar 60,08 m dan biaya material handling $\mathrm{Rp}$ 601,-- lebih efisien dari pada layout eksisting dengan jarak tempuh sebesar 172,87 $\mathrm{m}$ dan biaya material handling Rp 1.729,-.
\end{abstract}

Kata Kunci: Tata Letak Pabrik, Tata Letak Gudang, Metode Dedicated Storage.

\section{PENDAHULUAN}

Salah satu ciri tata letak yang baik yaitu memiliki efisiensi dalam pengambilan maupun penerimaan barang di dalam gudang. Dalam kondisi eksistingnya, perusahaan hanya menggunakan keranjang dalam sistem peletakannya yang disusun ke atas. Hal ini tentu saja membutuhkan waktu lama jika pengambilan barang terdapat pada keranjang yang paling bawah karena harus menurunkan keranjang yang berada di atasnya satupersatu. Tentu saja hal ini akan menyulitkan operator dalam mengatur maupun mengambil produk jadi untuk dikirim kepada konsumen karena membutuhkan waktu dan tenaga ekstra.

Permasalahan lainnya yang sering dihadapi oleh perusahaan adalah aliran produk jadi yang masuk dan keluar dari gudang produk jadi tidak terkoordinasi dengan baik. Hal tersebut akan menyulitkan operator dalam mengatur produk yang akan disimpan maupun diambil di gudang produk jadi karena diperlukan waktu pencarian produk dan jarak tempuh yang tidak tetap setiap kali proses pengambilan atau penyimpanan produk dilakukan. Setiap produk tentu saja harus disimpan di slot yang sama dengan produk yang sejenis. Apabila aliran produk tidak lancar maka akan menghambat proses aliran produk yang akan disimpan ke gudang maupun yang akan dikeluarkan dari gudang.

Untuk itu perlu dilakukan penataan lokasi penyimpanan produk pada gudang produk jadi dengan menggunakan metode dedicated storage sehingga aliran produk yang masuk dan keluar dari gudang produk jadi dapat terkoordinasi dengan baik dan penggunaan daerah penyimpanan pada gudang produk jadi akan menjadi optimal. Adapun tujuan dari metode ini adalah untuk memberikan usulan perbaikan tata letak gudang produk jadi yang lebih fleksibel terhadap pemindahan produk jadi di gudang, mendapatkan rancangan tata letak gudang produk jadi yang efektif, meminimalkan biaya simpan pada gudang dengan menghemat pemindahan dan pengaturan barang dalam gudang produk jadi. 


\section{HASIL DAN PEMBAHASAN}

Pada pengolahan data metode yang digunakan adalah metode dedicated storage. Adapun langkah-langkah menggunakan metode ini yaitu:

1) Menentukan permintaan produk rata-rata;

2) Menghitung space requirement yang dibutuhkan setiap produk;

3) Menghitung throughput setiap produk;

4) Membandingkan $T / S$ dan meranking hasil perhitungannya;

5) Menghitung jarak perjalanan tiap blok;

6) Merangkingkan jarak perjalanan tiap blok; dan

7) Menghitung jarak tempuh total perjalanan gudang eksisting dan usulan.

\section{Menentukan Permintaan Produk Rata- Rata}

\begin{tabular}{|l|c|c|c|c|c|c|c|c|}
\hline \multicolumn{10}{|c|}{ TABEL PRODUKSI } \\
\cline { 2 - 9 } & Ekado & $\begin{array}{c}\text { Kaki } \\
\text { Naga } \\
\text { Ikan }\end{array}$ & $\begin{array}{c}\text { Kaki } \\
\text { Naga } \\
\text { Udang }\end{array}$ & $\begin{array}{c}\text { Keong } \\
\text { Mas }\end{array}$ & $\begin{array}{c}\text { Bakso } \\
\text { Tuna }\end{array}$ & $\begin{array}{c}\text { Bakso } \\
\text { Puth }\end{array}$ & $\begin{array}{c}\text { Otak- } \\
\text { otak } \\
\text { Panjang }\end{array}$ & $\begin{array}{c}\text { Bakwan } \\
\text { Ikan }\end{array}$ \\
\hline Rata-rata & 216 & 197 & 224 & 132 & 258 & 169 & 155 & 157 \\
\hline \hline & & \multicolumn{7}{|c|}{ Jenis Produk (pack) } \\
\cline { 2 - 10 } & Ekado & $\begin{array}{c}\text { Kaki } \\
\text { Naga } \\
\text { Ikan }\end{array}$ & $\begin{array}{c}\text { Kaki } \\
\text { Naga } \\
\text { Udang }\end{array}$ & $\begin{array}{c}\text { Keong } \\
\text { Mas }\end{array}$ & $\begin{array}{c}\text { Bakso } \\
\text { Tuna }\end{array}$ & $\begin{array}{c}\text { Bakso } \\
\text { Puth }\end{array}$ & $\begin{array}{c}\text { Otak-otak } \\
\text { Panjang }\end{array}$ & $\begin{array}{c}\text { Bakwan } \\
\text { Ikan }\end{array}$ \\
\hline
\end{tabular}

\section{Menghitung Space Requirement yang} Dibutuhkan Setiap Produk

\begin{tabular}{|c|l|c|c|c|}
\hline No & Nama Produk & $\begin{array}{c}\text { Kapasitas } \\
\text { Packing dalam 1 } \\
\text { keranjang }\end{array}$ & $\begin{array}{c}\text { Penyimpanan } \\
\text { Maksimum (pack) }\end{array}$ & $\begin{array}{c}\text { Space Requirement } \\
\text { (slot) }\end{array}$ \\
\hline 1 & Ekado & 25 & 651 & 3 \\
\hline 2 & Kaki Naga Ikan & 25 & 1056 & 4 \\
\hline 3 & Kaki Naga Udang & 25 & 435 & 2 \\
\hline 4 & Keong Mas & 25 & 741 & 3 \\
\hline 5 & Bakso Tuna & 25 & 633 & 3 \\
\hline 6 & Bakso Puth & 25 & 414 & 2 \\
\hline 7 & Otak-otak Panjang & 25 & 385 & 2 \\
\hline 8 & Bakwan Ikan & 25 & 544 & 2 \\
\hline
\end{tabular}

Keranjang dapat menyimpan 1 jenis produk. Jumlah maksimal pengisian keranjang 25 pack. Setiap slot dapat menampung 10 keranjang disusun ke atas. Ukuran keranjang sebesar $20 \mathrm{~cm} \times 50 \mathrm{~cm}$. Contoh perhitungan produk ekado:

$$
S_{i j}=\frac{651}{(25 \times 10)}=2,604 \sim 3 \text { slot }
$$

3. Menghitung Throughput Setiap Pro$d u k$

\begin{tabular}{|c|c|c|c|c|c|c|c|c|}
\hline \multirow{2}{*}{ No } & \multirow{2}{*}{ Nama Produk } & \multicolumn{2}{|c|}{\begin{tabular}{|l|} 
Penerimanan rata-ratata \\
\end{tabular}} & \multirow{2}{*}{\begin{tabular}{|l|} 
Throughput \\
Penerimaan \\
\end{tabular}} & \multicolumn{2}{|c|}{$\begin{array}{l}\text { Pengiriman rata-rata } \\
\end{array}$} & \multirow{2}{*}{\begin{tabular}{|l|} 
Throughput \\
Pengirman \\
\end{tabular}} & \multirow{2}{*}{$\begin{array}{l}\text { Throughput } \\
\text { (Aktivitas) }\end{array}$} \\
\hline & & pack & $\begin{array}{l}\text { keranjang } \\
\end{array}$ & & pack & keranjang & & \\
\hline 1 & Ekado & 216 & 9 & 1 & 59 & 2 & 1 & 2 \\
\hline 2 & Kaki Naga Ikan & 197 & 8 & 1 & 42 & 2 & 1 & 2 \\
\hline 3 & Kaki Naga Udang & 224 & 9 & 1 & 22 & 1 & 1 & 2 \\
\hline 4 & Keong Mas & 132 & 5 & 1 & 67 & 3 & 1 & 2 \\
\hline 5 & Bakso Tuna & 258 & 10 & 1 & 122 & 5 & 1 & 2 \\
\hline 6 & Bakso Puth & 169 & 7 & 1 & 25 & 1 & 1 & 2 \\
\hline 7 & Otak-otak Panjang & 155 & 6 & 1 & 43 & 2 & 1 & 2 \\
\hline 8 & Bakwan Ikan & 157 & 6 & 1 & 17 & 1 & 1 & 2 \\
\hline
\end{tabular}

Setiap aktivitasnya menggunakan hand truck yang dapat mengangkut 12 keranjang.

\section{Membandingkan T/S dan Meranking Hasil Perhitungannya.}

\begin{tabular}{|c|l|c|}
\hline No & \multicolumn{1}{|c|}{ Nama Produk } & $T / S$ \\
\hline 1 & Otak-otak Panjang & 1,299 \\
\hline 2 & Bakso Putih & 1,208 \\
\hline 3 & Kaki Naga Udang & 1,149 \\
\hline 4 & BakwanIkan & 0,919 \\
\hline 5 & Bakso Tuna & 0,790 \\
\hline 6 & KeongMas & 0,675 \\
\hline 7 & Ekado & 0,667 \\
\hline 8 & Kaki Naga Ikan & 0,473 \\
\hline
\end{tabular}

Penempatan produk pada layout usulan berdasarkan pada nilai $T / S$ terbesar yang ditempatkan pada jarak tempuh terpendek, sehingga harus memperhitungkan $T / S$ untuk setiap produk, serta mengurutkannya dari nilai terkecil.

\section{Menghitung Jarak Perjalanan Tiap} Blok

\begin{tabular}{|c|c|c|c|c|c|c|c|c|c|c|c|}
\hline Blok & A1 & A2 & A3 & A4 & A5 & A6 & $\mathrm{Cl}$ & $\mathrm{C} 2$ & C3 & $\mathrm{C4}$ & C5 \\
\hline Jarak Total (m) & 7,5 & 6,5 & 5,5 & 4,5 & 3,5 & 2,5 & 17,5 & 16,5 & 15,5 & 14,5 & 13,5 \\
\hline Blok & c6 & C7 & $\mathrm{CB}$ & D1 & D2 & D3 & D4 & D5 & D6 & D7 & D8 \\
\hline Jarak Total(m) & 12,5 & 11,5 & 10,5 & 14,5 & 13,5 & 12,5 & 11,5 & 10,5 & 9,5 & 8,5 & 7,5 \\
\hline Blok & E1 & E2 & E3 & E4 & E5 & E6 & E7 & E8 & F1 & $\mathrm{F} 2$ & F3 \\
\hline Jarak Total (m) & 11,5 & 10,5 & 9,5 & 8,5 & 7,5 & 6,5 & 5,5 & 4,5 & 11,5 & 10,5 & 9,5 \\
\hline Blok & & & & & & & & & & & \\
\hline Diok & 54 & F5 & Fo & F7 & F8 & 61 & 62 & 63 & G4 & 65 & 66 \\
\hline Jarak Total (m) & 8,5 & 7,5 & 6,5 & 5,5 & 4,5 & 14,5 & 13,5 & 12,5 & 11,5 & 10,5 & 9,5 \\
\hline Blok & G7 & G8 & H1 & H2 & H3 & H4 & H5 & H6 & H7 & 11 & 12 \\
\hline Jarak Total(m) & 8,5 & 7,5 & 17,5 & 16,5 & 15,5 & 14,5 & 13,5 & 12,5 & 11,5 & 10,5 & 20,5 \\
\hline Blok & 12 & 13 & 14 & 15 & 16 & J1 & 32 & $J 3$ & 34 & 15 & 16 \\
\hline Jarak Total (m) & 19,5 & 18,5 & 17,5 & 16,5 & 15,5 & 15,5 & 16,5 & 17,5 & 18,5 & 19,5 & 20,5 \\
\hline
\end{tabular}

\section{Merangkingkan Jarak Perjalanan} Tiap Blok

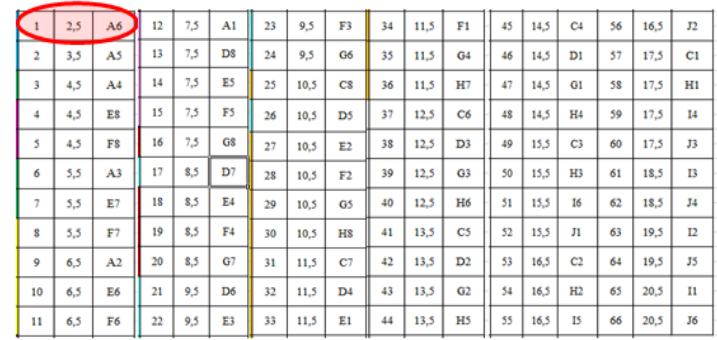




\section{Menghitung Jarak Tempuh Total Perjalanan Gudang Eksisting dan Usulan}

Lokasi penyimpanan eksisting digambarkan dalam bentuk area template yang memiliki 72 slot atau blok yang digunakan untuk menyimpan produk. Dalam satu blok dapat menampung 10 tumpukan keranjang ke atas. Terdapat juga blok untuk penyimpanan sementara yang berfungsi untuk meletakkan barang yang siap di kirim. Layout gudang eksisting dapat dilihat pada gambar berikut:

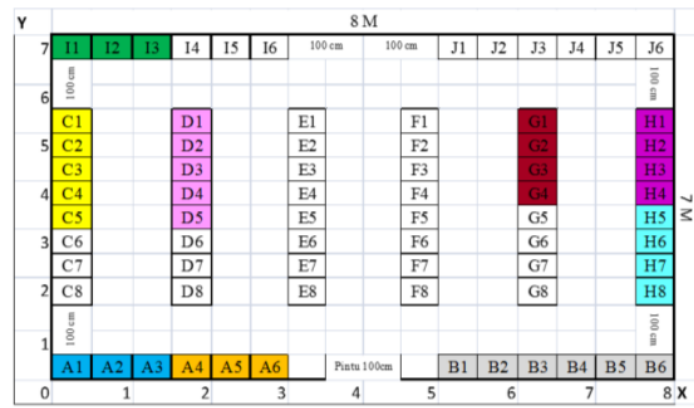

Gambar 1 Layout eksisting gudang produk jadi

Keterangan:

Nama Produk

\begin{tabular}{lll}
\hline Nama Produk & T/S & SR \\
\hline Otak-otak Panjang & 1,2993 \\
Bakso Putih & 1,2084 \\
Kaki Naga Udang & 1,1492 \\
Bakwan Ikan & 0,9193 \\
Bakso Tuna & 0,7903 \\
Keong Mas & 0,6752 \\
Ekado & 0,6672 \\
Kaki Naga Ikan & 0,4732
\end{tabular}

\section{Perhitungan Jarak Tempuh Gudang Eksisting}

\begin{tabular}{|c|c|c|c|}
\hline No & Nama Produk & Blok & Jarak Tempuh (m2) \\
\hline \multirow{3}{*}{1} & \multirow{3}{*}{ Bakso Putih } & $\mathrm{A} 1$ & \multirow{3}{*}{11,78} \\
\hline & & $\mathrm{A} 2$ & \\
\hline & & $\mathrm{A} 3$ & \\
\hline \multirow{3}{*}{2} & \multirow{3}{*}{ Bakso Tuna } & A4 & \multirow{3}{*}{4,15} \\
\hline & & A5 & \\
\hline & & A6 & \\
\hline \multirow{5}{*}{3} & \multirow{5}{*}{ Ekado } & C1 & \multirow{5}{*}{25,83} \\
\hline & & $\mathrm{C} 2$ & \\
\hline & & $\mathrm{C} 3$ & \\
\hline & & $\mathrm{C} 4$ & \\
\hline & & C5 & \\
\hline \multirow{5}{*}{4} & \multirow{5}{*}{ Keong Mas } & D1 & \multirow{5}{*}{21,09} \\
\hline & & D2 & \\
\hline & & $\mathrm{D} 3$ & \\
\hline & & D4 & \\
\hline & & D5 & \\
\hline \multirow{4}{*}{5} & \multirow{4}{*}{ Bakwan Ikan } & G1 & \multirow{4}{*}{23,90} \\
\hline & & G2 & \\
\hline & & G3 & \\
\hline & & G4 & \\
\hline \multirow{4}{*}{6} & \multirow{4}{*}{ Kaki Naga Udang } & $\mathrm{H} 1$ & \multirow{4}{*}{36,78} \\
\hline & & $\mathrm{H} 2$ & \\
\hline & & $\mathrm{H} 3$ & \\
\hline & & $\mathrm{H} 4$ & \\
\hline \multirow{3}{*}{7} & \multirow{3}{*}{ Kaki Naga Ikan } & H5 & \multirow{3}{*}{11,36} \\
\hline & & H6 & \\
\hline & & $\frac{\mathrm{H} 7}{\mathrm{H} 8}$ & \\
\hline \multirow{3}{*}{8} & \multirow{3}{*}{ Otak-otak Panjang } & I1 & \multirow{3}{*}{37,99} \\
\hline & & 12 & \\
\hline & & 13 & \\
\hline \multicolumn{3}{|c|}{ TOTAL JARAK TEMPUH } & 172,87 \\
\hline
\end{tabular}

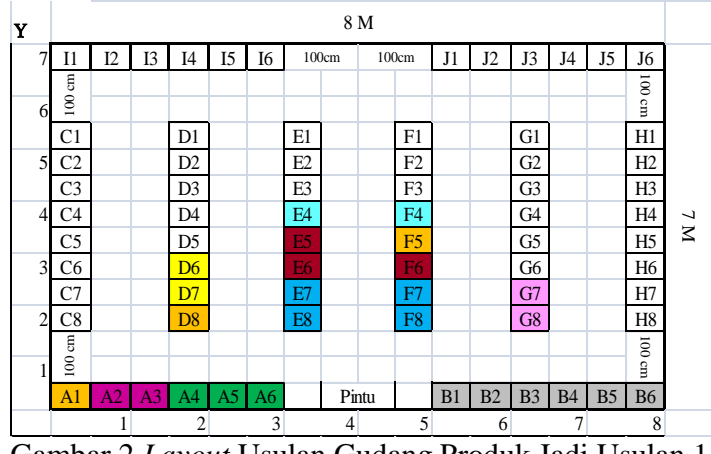

Gambar 2 Layout Usulan Gudang Produk Jadi Usulan 1

\section{Keterangan:}

Nama Produk

\begin{tabular}{lll} 
Nama Produk & T/S SR \\
\hline Otak-otak Panjang & 1,2993 \\
Bakso Putih & 1,2084 \\
Kaki Naga Udang & 1,1492 \\
Bakwan Ikan & 0,9193 \\
Bakso Tuna & 0,7903 \\
Keong Mas & 0,6752 \\
Ekado & 0,6672 \\
Kaki Naga Ikan & 0,4732
\end{tabular}

\section{Perhitungan Jarak Tempuh Gudang Usulan 1}

Tabel 2 Perhitungan Jarak Tempuh Usulan 1

\begin{tabular}{|c|c|c|c|}
\hline No & Nama Produk & Blok & $\begin{array}{c}\text { Jarak } \\
\text { Tempuh }\end{array}$ \\
\hline \multirow{3}{*}{1} & \multirow{3}{*}{ Otak-otak Panjang } & A4 & \multirow{3}{*}{6,83} \\
\hline & & A5 & \\
\hline & & A6 & \\
\hline \multirow{4}{*}{2} & \multirow{4}{*}{ Bakso Putih } & E7 & \multirow{4}{*}{12} \\
\hline & & E8 & \\
\hline & & F7 & \\
\hline & & F8 & \\
\hline \multirow{2}{*}{3} & \multirow{2}{*}{ Kaki Naga Udang } & A2 & \multirow{2}{*}{6,84} \\
\hline & & A3 & \\
\hline \multirow{3}{*}{4} & \multirow{3}{*}{ Bakwan Ikan } & E5 & \multirow{3}{*}{9,43} \\
\hline & & E6 & \\
\hline & & F6 & \\
\hline \multirow{3}{*}{5} & \multirow{3}{*}{ Bakso Tuna } & D6 & \multirow{3}{*}{9,95} \\
\hline & & D7 & \\
\hline & & D8 & \\
\hline \multirow{2}{*}{6} & \multirow{2}{*}{ Keong Mas } & F4 & \multirow{2}{*}{5,44} \\
\hline & & F5 & \\
\hline \multirow{2}{*}{7} & \multirow{2}{*}{ Ekado } & G7 & \multirow{2}{*}{5,28} \\
\hline & & G8 & \\
\hline \multirow{2}{*}{8} & \multirow{2}{*}{ Kaki Naga Ikan } & E3 & \multirow{2}{*}{4,32} \\
\hline & & E4 & \\
\hline \multicolumn{3}{|c|}{ Total Jarak Tem } & 60,08 \\
\hline
\end{tabular}


Tabel 3 Perhitungan Jarak Tempuh Usulan 2

\begin{tabular}{|c|c|c|c|}
\hline No & Nama Produk & Blok & $\begin{array}{c}\text { Jarak } \\
\text { Tempuh }\end{array}$ \\
\hline \multirow{3}{*}{1} & \multirow{3}{*}{ Otak-otak Panjang } & A4 & \multirow{3}{*}{6,83} \\
\hline & & A5 & \\
\hline & & A6 & \\
\hline \multirow{4}{*}{2} & \multirow{4}{*}{ Bakso Putih } & E7 & \multirow{4}{*}{12} \\
\hline & & E8 & \\
\hline & & F7 & \\
\hline & & F8 & \\
\hline \multirow{2}{*}{3} & \multirow{2}{*}{ Kaki Naga Udang } & $\mathrm{A} 2$ & \multirow{2}{*}{6,84} \\
\hline & & A3 & \\
\hline \multirow{3}{*}{4} & \multirow{3}{*}{ Bakwan Ikan } & E5 & \multirow{3}{*}{9,43} \\
\hline & & E6 & \\
\hline & & F6 & \\
\hline \multirow{3}{*}{5} & \multirow{3}{*}{ Bakso Tuna } & A1 & \multirow{3}{*}{8,78} \\
\hline & & D8 & \\
\hline & & F5 & \\
\hline \multirow{2}{*}{6} & \multirow{2}{*}{ Keong Mas } & G7 & \multirow{2}{*}{5,44} \\
\hline & & G8 & \\
\hline \multirow{2}{*}{7} & \multirow{2}{*}{ Ekado } & D6 & \multirow{2}{*}{5,94} \\
\hline & & D7 & \\
\hline \multirow{2}{*}{8} & \multirow{2}{*}{ Kaki Naga Ikan } & E4 & \multirow{2}{*}{4,08} \\
\hline & & $\mathrm{F} 4$ & \\
\hline
\end{tabular}

Berdasarkan dari hasil perhitungan pada tabel di atas, nilai total jarak tempuh sebesar 59,33 Penurunan jarak total dari usulan ini sebesar 65,68 \%. Dari hasil layout usulan 1, terlihat pada layout usulan 1 di atas tampak ganjil pada blok A1, D8, dan F5 yang merupakan blok produk bakso tuna berada berjauhan tidak berada dalam satu lokasi sesuai dengan jenis produk sehingga aktivitas operator belum sepenuhnya efisien dalam pencarian produk. Selain itu estetika penempatan kurang teratur. Sedangkan layout tersebut sudah sesuai dengan urutan penempatan. Maka dari itu perlu dibandingkan dengan usulan lain dengan menambahkan unsur estetika namun tetap pada tata cara penempatan produk dengan metode dedicated storage.

\section{Layout Usulan 2 Gudang Produk Jadi}

Pada usulan 2 ini, melakukan perubahan posisi pada produk Bakso Tuna dengan mempertimbangkan aktivitas operator dalam proses pencarian karena pada layout usulan 1, penempatan produk bakso tuna berada di barisan blok yang berbeda yaitu A1, D8, dan F5. Produk bakso tuna di tempatkan pada blok F3, F4, F5 dengan mempertimbangkan beberapa iterasi perhitungan yang mendekati pada hasil usulan 1. Berikut gambar layout usulan 2:

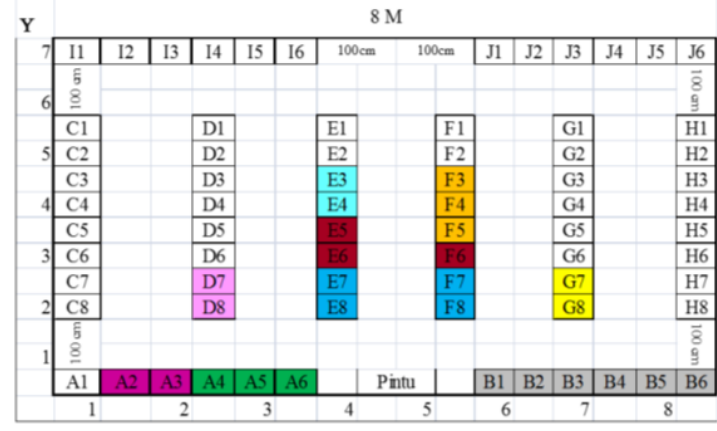

Gambar 3 Layout usulan gudang produk jadi

Keterangan:

Nama Produk

\begin{tabular}{lc} 
Nama Produk & T/S SR \\
\hline \hline Otak-otak Panjang & 1,2993 \\
Bakso Putih & 1,2084 \\
Kaki Naga Udang & 1,1492 \\
Bakwan Ikan & 0,9193 \\
Bakso Tuna & 0,7903 \\
Keong Mas & 0,6752 \\
Ekado & 0,6672
\end{tabular}

\section{Kaki Naga Ikan 0,4732}

Tampak pada layout usulan diatas, letak posisi blok untuk produk bakso tuna telah berada di lokasi yang berdekatan yaitu sama-sama berada pada barisan F. Usulan tersebut selain untuk memudahkan pencarian produk oleh operator, juga memberikan estetika yang tampak baik. Namun jarak tempuh juga turut akan berubah melihat posisi blok yang berpindah.

Kedua usulan tersebut tetap pada porsi nya dengan menggunakan tata cara yang sesuai dengan alurnya yaitu mempertimbangkan space requirement, perangkingan $T / S$, dan penempatan produk berdasarkan perangkingan total jarak blok. Dari segi jarak tempuh dan biaya, usulan 1 memegang peranan terbaik.

Namun jika dipilih usulan 1 ini, operator akan sulit dalam mencari produk yang diperlukan. Selain itu juga aktivitas operator menjadi tidak efisien karena keberadaan blok yang tidak berada pada satu baris atau saling berdekatan satu sama lain sehingga tampak tidak rapi dalam penyusunannya.

Untuk dipertimbangkan lagi dari segi efisiensi operator dalam melaksanakan tugas, usulan 2 lebih efisien karena letak blok yang berdekatan yang berada pada 1 barisan dapat memudahan operator dalam prose proses pencarian produk yang dituju dan terlihat rapi dalam penyusunan produk. 
Pada keadaan eksisting menghasilkan jarak tempuh sejauh $172,87 \mathrm{~m}$. Sedangkan jarak usulan yang dipilih sebesar $60,08 \mathrm{~m}$. Pada perhitungan tersebut jarak usulan mengalami penurunan dikarenakan beberapa hal, yaitu dalam jumlah pemakaian blok eksisting yang berjumlah 31 blok, sedangkan kebutuhan ruang yang dipakai hanya 20 blok saja.

Selain itu penempatan produk pada layout eksisting, tidak berdasarkan perangkingan $T / S$ dan jarak total, maka pada keadaan sebenarnya ada beberapa produk yang memiliki nilai throughput tertinggi namun tidak ditempatkan pada titik terdekat I/O point. Tentu saja hal tersebut menyebabkan jarak tempuh eksisting lebih jauh dibandingkan dengan jarak tempuh usulan yang dipilih.

Tabel 4. Perbandingan Layout Eksisting dan Layout Usulan

\begin{tabular}{|c|c|c|}
\hline & Layout Eksisting & Layout Usulan Terpilih \\
\hline $\begin{array}{l}\text { Space } \\
\text { Requirement }\end{array}$ & 31 blok & 20 blok \\
\hline $\begin{array}{l}\text { Jarak } \\
\text { Tempuh }\end{array}$ & $172,87 \mathrm{~m}$ & $60,08 \mathrm{~m}$ \\
\hline $\begin{array}{l}\text { Pemakaian } \\
\text { Blok }\end{array}$ & 31 blok & 20 blok \\
\hline $\begin{array}{l}\text { Penempatan } \\
\text { Barang }\end{array}$ & $\begin{array}{l}\text { Produk-produk disusun tanpa } \\
\text { memperhatikan tingkat perang- } \\
\text { kingan aktivitas fast-moving } \\
\text { dan slow-moving, sehingga be- } \\
\text { berapa produk yang memiliki } \\
\text { fast-moving tertinggi ditempat- } \\
\text { kan pada blok terjauh dari titik } \\
\text { IO point. Hal ini tentu saja } \\
\text { tidak efisien karena menyebab- } \\
\text { kan jarak tempuh dan biaya } \\
\text { menjadi besar. }\end{array}$ & $\begin{array}{l}\text { Seluruh produk telah ditem- } \\
\text { patkan berdasarkan aktivitas } \\
\text { fast-moving dan slow-moving } \\
\text { perangkingan sesuai dengan per- } \\
\text { hitungan metode dedicated } \\
\text { storage. Hal ini akan memberi } \\
\text { dampak yang efisien dalam segi } \\
\text { jarak tempuh, biaya, dan kemu- } \\
\text { dahan pekerjaan operator. }\end{array}$ \\
\hline
\end{tabular}

\section{KESIMPULAN}

Berdasarkan penelitian yang telah dilakukan dapat di ambil kesimpulan sebagai berikut:

1. Hasil perhitungan tata letak gudang produk jadi dengan menggunakan metode dedicated storage:

a) Space Requirement yang dibutuhkan sebanyak 20 slot;

b) Total throughput sebanyak 16 aktivitas;

c) Perbandingan $T / S$ menghasilkan produk otak-otak panjang diletakkan dekat dengan titik $I / O$ point, sedangkan titik terjauh terdapat pada produk kaki naga ikan;

d) Perhitungan jarak perjalanan tiap blok yang terdekat dengan jarak 2,5 $\mathrm{m}$ dari titik I/O point diperoleh oleh blok A6. Sedangkan blok terjauh dengan jarak 20,5 $\mathrm{m}$ diperoleh oleh blok J6. e) Total jarak tempuh gudang produk jadi eksisting sebesar 172, $87 \mathrm{~m}$.

f) Total jarak tempuh gudang produk jadi usulan 1 sebesar 59,33 m. Total jarak gudang produk jadi usulan 2 sebesar 60,08 m.

g) Penurunan total jarak pada usulan 1 sebesar $65,68 \%$ sedangkan pada usulan 2 sebesar $65,25 \%$.

h) Usulan yang dipilih adalah usulan 2 .

2. Analisis Usulan tata letak gudang produk jadi dengan menggunakan metode dedicated storage:

a) Usulan yang terpilih yaitu usulan 2, dengan total jarak tempuh $60,08 \mathrm{~m}$.

b) Selisih jarak tempuh eksisting dengan usulan sebanyak 112,79 m. Usulan tersebut dipilih karena selain sudah memenuhi syarat-syarat penempatan produk, usulan ini juga mengandung estetika dan efisiensi waktu dalam pencarian produk jadi oleh operator.

\section{DAFTAR PUSTAKA}

Abdullah, Fikrie. 2009. Usulan Perbaikan Tata Letak Gudang Produk Jadi Dengan Menggunakan Metode Dedicated Storage di PT Cahaya Kawi Ultra Polyintraco. Tugas Sarjana, 59, 60-61, 65-67.

Apple J.M. 1990. Tata Letak Pabrik dan Pemindahan Bahan. Penerjemah: Nurhayati Mardiono. Bandung: ITB. Hal. 18-19, 246.

Djunaidi, dkk. 2006. Simulasi Group Technology System Untuk Meminimalkan Biaya Material Handling Dengan Metode Heuristic. Jurnal Ilmiah Teknik Industri, Vol. 4, No. 3, hal 2-3.

Hadi Permana, Irfan. 2014. Relayout Tata Letak Gudang Produk Jadi Baja Tulangan Dengan Menggunakan Metode Dedicated Storage pada PT. ABC. Skripsi, 20, 24, 25, 26-27, 2829.

Juliana, Heldy. 2016. Peningkatan Kapasitas Gudang Dengan Perancangan Layout Menggunakan Metode Class- 
Based Storage. Jurnal Teknik Industri, hal 3.

Kurniawan, Ivan. 2009. Perbaikan Tata Letak Gudang Pada PR Sukun Sigaret Menggunakan Metode Shared
Storage. Tugas Akhir, hal 25-26, 27, 28-30, 31.

Wignjoesoebroto, Sritomo. 2009. Tata Letak Pabrik dan Pemindahan Bahan. Surabaya: Guna Widya. Hal 72-75. 